\title{
Diagnosis of limiting factors of organic oilseed rape yield. A survey of farmers' fields
}

\author{
Muriel VALANTIN-MORISON ${ }^{1 *}$, J.M. MEYNARD $^{2}$ \\ ${ }^{1}$ UMR 211, Agronomie INRA-AgroParisTech, BP 01, 78850 Thiverval-Grignon, France \\ ${ }^{2}$ Département INRA “Sciences pour l'Action et le Développement”, BP 01, 78850 Thiverval-Grignon, France
}

(Accepted 7 May 2008)

\begin{abstract}
The yield of organic winter oilseed rape (WOSR) crop is low and variable in organic farming, but the reasons responsible for this problem are not clear. Aiming to identify the factors affecting organic oilseed rape yields, we carried out a diagnostic study on a network of 19 farmers' fields in four contrasting regions of France over a two-year period. Weed density and biomass, nitrogen absorption by the crop and by weeds, and nutrient availability in the soil, as well as the occurrence of pests and diseases, were assessed at four developmental stages. A range of possible limiting factors throughout the crop cycle led us to use a regression procedure for different periods, using the yield components during spring and biomass during autumn as dependent variables. We identified factors limiting yield and the critical time points at which they acted, which has never been done. Yield variation was strongly correlated with number of grains. $\mathrm{m}^{-2}$. Dry biomass of weeds, nitrogen uptake by weeds and density of weeds appeared to explain $39 \%$ of variation in crop biomass in early winter, while pollen beetle and rape stem weevil damage explained $4.5 \%$ and $12 \%$ of variation in the number of flowers. $\mathrm{m}^{-2}$ and the number of branches.m $\mathrm{m}^{-2}$, respectively. Crop nitrogen deficiencies occurring before branching were strongly correlated with weed biomass in flowering. Analysis of covariance showed that sowing date, soil management and the quantity of organic manure application may have significantly affected the nitrogen nutrition index, nitrogen uptake by plants and ratio of weed biomass: a late sowing date and shallow soil tillage were related to a low crop nitrogen nutrition index and high ratio of weed biomass. From a practical point of view, this study demonstrated that it should be possible to reduce weed competition by ensuring that the amount of nitrogen in soil before sowing is around $100 \mathrm{~kg} / \mathrm{ha}$.
\end{abstract}

winter oilseed rape / organic farming / yield variability / yield components / diagnosis / farmers' fields / nitrogen deficiencies / weed competitio

\section{INTRODUCTION}

Winter oilseed rape (WOSR) is not widely used in French organic farming as its yield is low and unpredictable. However, this crop is of potential value in terms of market requirements and agronomic potential. Its oil is particularly beneficial for human health as it contains omega 3 fatty acids (Renaud, 1996; Bourre, 1996). Moreover, oilseed rape cake is a source of low-cost proteins that could be used as a supplement to correct the protein deficiencies of cereals for animal feeding in organic farming. Besides, oilseed rape is of agronomic value for several reasons, some of which are particularly relevant in organic farming. First, the inclusion of oilseed rape in a crop rotation is known to be of benefit for the following wheat crop. Kirkegaard and Sarwar (1998), and Smith and

\footnotetext{
* Corresponding authors:

morison@grignon.inra.fr, meynard@grignon.inra.fr
}

Kirkegaard (2002) demonstrated that, as for other brassicas, the glucosinolates present in crop residues have biofumigation potential, which may be effective against take-all (Gaeumannomyces graminis). Second, oilseed rape traps nitrate efficiently in autumn (Vos and Van der Putten, 1997; Dejoux et al., 2003), reducing the risk of nitrate leaching during winter. Moreover, oilseed rape residues also return large amounts of nitrogen to the soil after harvest (Trinsoutrot et al., 2000; Dorsainvil, 2002), which is interesting in low-input systems.

The major factors limiting oilseed rape yields in conventional farming are well documented (Merrien and Pouzet, 1988; Williams et al., 1991; Dejoux et al., 2003). Most of these studies have stressed the importance of abiotic factors such as nitrogen and water. They have identified the yield components affected by these limiting factors and the times at which these factors act. Indeed, spring deficiencies have a much greater effect on yield than autumn deficiencies because of their effects on the number of flowers and seed abortion (Colnenne et al., 
2002). Biotic factors often affect the yield of organic crops (David et al., 2005). Weeds are generally thought to present the most serious threat to organic oilseed rape production (Penfold et al., 1995; Clark et al., 1999). Moreover, oilseed rape is known to be attacked by numerous insects, especially coleoptera, which are difficult to control without chemical treatments. Many studies concern the biology of Delia spp. (Dosdall et al., 1996, 1998) and Meligethes aeneus (Nilsson, 1994; Ekbom and Ferdinand, 2003; Cook et al., 2004) but few studies have dealt with the application of such research to integrated pest management, except Cook et al. (2002).

Previous studies have investigated the factors affecting oilseed rape yield in conventional agriculture, but no such research has been carried out on organic oilseed rape. In this study, we aimed to identify the major factors limiting oilseed rape yields and the main cultural practices connected with these limiting factors in organic farming.

\section{MATERIALS AND METHODS}

We used a diagnosis method (Meynard and David, 1992; Doré et al., 1997) that has been used on many crops, including oilseed rape (Dejoux et al., 2003). The method involves determining and explaining the relationships between characteristics of the crop such as biomass, yield components and nutrient status, the occurrence of pests, weeds and diseases, and cropping practices, soil characteristics and weather on a farmers' field network. The analysis comprises three stages: (i) identifying the yield components that best explain yield variations; (ii) identifying the environmental conditions and limiting factors that act on these yield components; and (iii) specifying the characteristics of the cropping system, climate and soil that create favourable or unfavourable environmental conditions.

\subsection{Experimental design}

A network of 19 farmers' fields (Tab. I) in four regions with contrasting climatic and soil conditions was studied over a two-year period (Fig. 1). Each field was coded, a letter identifying the farm and a number referring to year. Farms A to E are located in the center of France (Auvergne); fields A01 and A02 are therefore two different fields on the same farm in 2001 and 2002, respectively. Farms F to K are located in southern France (Rhône-Alpes); farms L to M are located near Paris (North 1), and farms $\mathrm{O}$ and $\mathrm{P}$ are located in the eastern Paris basin (North 2). Field size ranged from 1 to 11 ha. We minimised the effects of this heterogeneity on our measurements by studying a part of each field ( $50 \mathrm{~m} \times 100 \mathrm{~m}$ minimum) homogeneous in soil type and crop density. Farmers made their own decisions concerning crop management.

In 14 out of 19 cases, the previous crop was a cereal (Tab. I), and in 15 cases the oilseed rape crop was sown after August 10th (Tab. I). In our field network, oilseed rape was sometimes preceded by cereals other than wheat, such as triticale, or legumes, such as pea (farms A and B), if organic manure

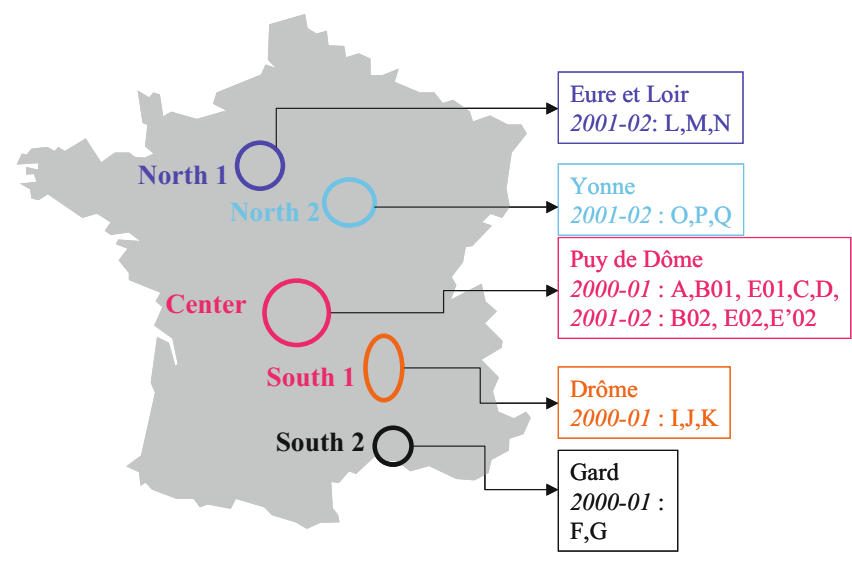

Figure 1. Location of the 19 fields according to the year and the region of France (Center, North 1 - west of Paris - and North 2 south-east of Paris -, South 1 - south of Lyon - and South 2 - near Montpellier) and the name of the département.

was not readily available. The oilseed rape crop always preceded wheat in the rotation. Most farmers applied manure before sowing (two farmers spread manure before sowing of the preceding crop) and applied no nitrogen fertiliser or manure in spring. No mechanical weeding was carried out in about half the fields (10 out of 19).

\subsection{Measurements and observations}

Plants: On each plot, whole plants were sampled at four different times: (i) in early winter, before winter drainage and the occurrence of low temperatures (early November in northern France and early December in southern France), (ii) in late winter (end of January in the south and mid-February in the north), (iii) early flowering (Sylvester-Bradley (1985) Growth Stage 4.5 - beginning of April), and (iv) pod filling and most seeds green (Growth Stage 6.3 - beginning of June). On each occasion samples were taken from eight (2001) or six (2002) microplots of $0.5 \mathrm{~m}^{2}$. The plants were counted and the roots separated from the aerial parts after washing. Dry biomass (after $48 \mathrm{~h}$ of drying at $80^{\circ} \mathrm{C}$ ) and total nitrogen content of green aerial parts and tap roots (Dumas method) were determined for each microplot sample. We calculated the nitrogen nutrition index (NNI; Lemaire et al., 1997) as the ratio between the nitrogen content of the aerial parts of the plant and critical nitrogen content, using the reference values of critical $\mathrm{N}$ content for oilseed rape proposed by Colnenne et al. (1998). The numbers of branches, flowers and fertile pods per plant were counted on 15 randomly chosen plants per microplot at the pod-filling stage. The crop was harvested with a combine harvester, and yield was estimated on two plots of $150 \mathrm{~m}^{2}$ to $400 \mathrm{~m}^{2}$. Moisture content and mean grain weight were determined in a sub-sample of $500 \mathrm{~g}$ of grain. The number of grains per $\mathrm{m}^{2}$ was estimated from yield and mean grain weight.

Soil: Soil and subsoil mineral nitrogen contents were determined by colorimetry after extraction in a solution of $1 \mathrm{~N} \mathrm{KCl}$, on the day of sampling. A sample from the $0-30 \mathrm{~cm}$ layer from 
Table I. Main cultural practices in the fields of the network; mineral nitrogen content was calculated from the mineral and organic nitrogen content of fresh manure and the amount of manure spread.

\begin{tabular}{|c|c|c|c|c|c|c|c|c|c|}
\hline $\begin{array}{l}\text { Farm } \\
\text { fields }\end{array}$ & $\begin{array}{l}\text { Soil man- } \\
\text { agement } \\
\text { before } \\
\text { sowing }\end{array}$ & $\begin{array}{l}\text { Soil type } \\
\text { (soil depth } \\
-\mathrm{cm} \text { ) }\end{array}$ & $\begin{array}{l}\text { Crop } \\
\text { preceding } \\
\text { WOSR }\end{array}$ & Cultivar & $\begin{array}{l}\text { Sowing } \\
\text { date }\end{array}$ & $\begin{array}{l}\text { Plant } \\
\text { density at } \\
\text { emergence } \\
\left(\text { per } \mathrm{m}^{2}\right)\end{array}$ & $\begin{array}{l}\text { Organic manure } \\
\text { spread before } \\
\text { sowing (date, type, } \\
\text { amount) }\end{array}$ & $\begin{array}{l}\text { Mineral and } \\
\text { organic } \\
\text { nitrogen } \\
\text { available in } \\
\text { the organic } \\
\text { manure } \\
\text { spread }(\mathrm{kg} / \mathrm{ha})^{*}\end{array}$ & $\begin{array}{l}\text { Mechanical } \\
\text { tools used } \\
\text { for weeding } \\
\text { (number of } \\
\text { times) }\end{array}$ \\
\hline $\mathrm{A}_{01}$ & $\begin{array}{l}\text { Shallow } \\
\text { soil } \\
\text { tillage }\end{array}$ & $\begin{array}{l}\mathrm{Sa} \\
(60)\end{array}$ & Pea & Navajo & $21 / 08 / 2000$ & 64 & 0 & & $\begin{array}{l}\text { Weed } \\
\text { harrow (2) }\end{array}$ \\
\hline $\mathrm{B}_{01}$ & $\begin{array}{l}\text { Shallow } \\
\text { soil } \\
\text { tillage }\end{array}$ & $\begin{array}{l}\mathrm{SaC} \\
(90)\end{array}$ & Pea & Navajo & $21 / 08 / 2000$ & 77 & 0 & & $\begin{array}{l}\text { Weed } \\
\text { harrow (2) }\end{array}$ \\
\hline $\mathrm{B}_{02}$ & $\begin{array}{l}\text { Shallow } \\
\text { soil } \\
\text { tillage }\end{array}$ & $\begin{array}{l}\mathrm{SaC} \\
(60)\end{array}$ & Pea & Pollen & $27 / 08 / 2001$ & 45 & $\begin{array}{l}7 / 08 / 2001 \\
20 \text { t/ha pig manure }\end{array}$ & $\begin{array}{l}13.5 \\
400\end{array}$ & $\begin{array}{l}\text { Weed } \\
\text { harrow (2) }\end{array}$ \\
\hline $\mathrm{C}_{01}$ & $\begin{array}{l}\text { Shallow } \\
\text { soil } \\
\text { tillage }\end{array}$ & $\begin{array}{l}\text { Csi } \\
(90)\end{array}$ & Barley & Navajo & $16 / 08 / 2000$ & 67 & $\begin{array}{l}09 / 1999 \\
10 \mathrm{t} / \text { ha compost of } \\
\text { cowshed manure }\end{array}$ & & $\begin{array}{l}\text { Weed } \\
\text { harrow (1) }\end{array}$ \\
\hline $\mathrm{D}_{01}$ & $\begin{array}{l}\text { Shallow } \\
\text { soil } \\
\text { tillage }\end{array}$ & $\begin{array}{l}\text { Csa } \\
(90)\end{array}$ & Barley & Navajo & $16 / 08 / 2000$ & 66 & $\begin{array}{l}09 / 1999 \\
10 \mathrm{t} / \text { ha compost of } \\
\text { cowshed manure }\end{array}$ & & $\begin{array}{l}\text { Weed } \\
\text { harrow (1) }\end{array}$ \\
\hline $\mathrm{E}_{01}$ & Ploughing & $\begin{array}{l}\text { Csi } \\
(120)\end{array}$ & $\begin{array}{l}\text { Winter } \\
\text { wheat }\end{array}$ & Navajo & $26 / 08 / 2000$ & 80 & $\begin{array}{l}13 / 08 / 2000 \\
3 \mathrm{t} / \mathrm{ha} \text { compost of } \\
\text { cowshed manure }\end{array}$ & & $\begin{array}{l}\text { Weed } \\
\text { harrow (2) }\end{array}$ \\
\hline $\mathrm{E}_{02}$ & $\begin{array}{l}\text { Shallow } \\
\text { soil } \\
\text { tillage }\end{array}$ & $\begin{array}{l}\text { Csi } \\
(120)\end{array}$ & $\begin{array}{l}\text { Winter } \\
\text { wheat }\end{array}$ & Pollen & $8 / 09 / 2001$ & 65 & $\begin{array}{l}29 / 07 / 2001 \\
600 \mathrm{~kg} / \mathrm{ha} \text { organic } \\
\text { fertiliser }\end{array}$ & $\begin{array}{l}54 \\
398\end{array}$ & $\begin{array}{l}\text { Hoeing } \\
\text { machine (1) }\end{array}$ \\
\hline$E_{02}^{\prime}$ & $\begin{array}{l}\text { Shallow } \\
\text { soil } \\
\text { tillage }\end{array}$ & $\begin{array}{l}\text { Csi } \\
(120)\end{array}$ & $\begin{array}{l}\text { Winter } \\
\text { wheat }\end{array}$ & Pollen & $25 / 08 / 2001$ & 67 & $\begin{array}{l}29 / 07 / 2001 \\
600 \mathrm{~kg} / \mathrm{ha} \text { organic } \\
\text { fertiliser }\end{array}$ & $\begin{array}{l}54 \\
398\end{array}$ & - \\
\hline $\mathrm{F}_{01}$ & Ploughing & $\begin{array}{l}\mathrm{SiSa} \\
(60)\end{array}$ & $\begin{array}{l}\text { Durum } \\
\text { wheat }\end{array}$ & Constant & $26 / 09 / 2000$ & 70 & $\begin{array}{l}15 / 09 / 2000 \\
12 \mathrm{t} / \mathrm{ha} \text { compost of } \\
\text { fowl manure }\end{array}$ & & - \\
\hline $\mathrm{G}_{01}$ & Ploughing & $\begin{array}{l}\mathrm{SiSa} \\
(60)\end{array}$ & $\begin{array}{l}\text { Durum } \\
\text { wheat }\end{array}$ & Constant & 26/09/2000 & 110 & $\begin{array}{l}15 / 09 / 2000 \\
6 \mathrm{t} / \mathrm{ha} \text { compost of } \\
\text { fowl manure }\end{array}$ & & - \\
\hline $\mathrm{I}_{01}$ & Ploughing & $\begin{array}{l}\mathrm{SaSi} \\
(40)\end{array}$ & Barley & Navajo & $25 / 08 / 2000$ & 72 & $\begin{array}{l}10 / 01 / 2001 \\
\text { organic fertiliser }\end{array}$ & & - \\
\hline $\mathrm{J}_{01}$ & Ploughing & $\begin{array}{l}\mathrm{SaSi} \\
(90)\end{array}$ & Fallow & Navajo & $25 / 08 / 2000$ & 76 & $\begin{array}{l}10 / 01 / 2001 \\
\text { organic fertiliser }\end{array}$ & & - \\
\hline $\mathrm{K}_{01}$ & Ploughing & $\begin{array}{l}\mathrm{SaSi} \\
(90)\end{array}$ & Fallow & Colosse & $10 / 08 / 2000$ & 50 & $\begin{array}{l}? \\
6 \mathrm{t} / \text { ha compost of } \\
\text { fowl manure }\end{array}$ & & - \\
\hline $\mathrm{L}_{02}$ & Ploughing & $\begin{array}{l}\mathrm{SiC} \\
(120)\end{array}$ & $\begin{array}{l}\text { Winter } \\
\text { wheat }\end{array}$ & Pollen & $23 / 08 / 2001$ & 48 & $\begin{array}{l}3 / 08 / 2001 \\
2.5 \mathrm{t} / \text { ha compost of } \\
\text { fowl manure }\end{array}$ & $\begin{array}{l}8 \\
70\end{array}$ & $\begin{array}{l}\text { Hoeing } \\
\text { machine (1) }\end{array}$ \\
\hline $\mathrm{M}_{02}$ & Ploughing & $\begin{array}{l}\mathrm{SiSa} \\
(60)\end{array}$ & Pea/triticale & Pollen & $5 / 09 / 2001$ & 47 & $\begin{array}{l}3 / 08 / 2001 \\
20 \mathrm{t} / \mathrm{ha} \text { compost of } \\
\text { goat manure }\end{array}$ & $\begin{array}{l}33 \\
560\end{array}$ & - \\
\hline $\mathrm{N}_{02}$ & Ploughing & $\begin{array}{l}\mathrm{SiC} \\
(120)\end{array}$ & Triticale & Pollen & $3 / 09 / 2001$ & 43 & $\begin{array}{l}2 / 08 / 2001 \\
40 \mathrm{t} / \mathrm{ha} \text { compost of } \\
\text { horse manure and } \\
\text { plant residues }\end{array}$ & $\begin{array}{l}18.5 \\
544\end{array}$ & - \\
\hline $\mathrm{O}_{02}$ & Ploughing & $\begin{array}{l}\mathrm{SiC} \\
(30)\end{array}$ & Triticale & Pollen & $8 / 08 / 2001$ & 53 & $\begin{array}{l}29 / 07 / 2001 \\
18 \mathrm{t} / \mathrm{ha} \text { compost } \\
\text { of cowshed manure }\end{array}$ & $\begin{array}{l}109 \\
531\end{array}$ & - \\
\hline $\mathrm{P}_{02}$ & $\begin{array}{l}\text { Shallow } \\
\text { soil } \\
\text { tillage }\end{array}$ & $\begin{array}{l}\mathrm{SiSa} \\
(30)\end{array}$ & Wheat & Pollen & $10 / 08 / 2001$ & 104 & $\begin{array}{l}8 / 08 / 2001 \\
25 \mathrm{t} / \mathrm{ha} \text { compost of } \\
\text { fowl manure }\end{array}$ & $\begin{array}{l}10 \\
512\end{array}$ & - \\
\hline $\mathrm{Q}_{02}$ & $\begin{array}{l}\text { Shallow } \\
\text { soil } \\
\text { tillage }\end{array}$ & $\begin{array}{l}\mathrm{SiSa} \\
(90)\end{array}$ & Barley & Pollen & $23 / 08 / 2001$ & 98 & $\begin{array}{l}26 / 07 / 2001 \\
20 \mathrm{t} / \mathrm{ha} \text { compost of } \\
\text { horse manure }\end{array}$ & $\begin{array}{l}11 \\
610\end{array}$ & $\begin{array}{l}\text { Hoeing } \\
\text { machine (1) }\end{array}$ \\
\hline
\end{tabular}

* Analyses of organic manures were not carried out in the first year.

Shallow tillage: chisel or cover crop.

Si: silt; Sa: sand; C: clay. Characteristics of soil were encoded on the basis of texture analysis. 
each field was analysed by the INRA laboratory in Arras: to determine particle size and chemical composition: assimilate $\mathrm{P}$ - Olsen -, exchangeable $\mathrm{Mg}$ and $\mathrm{K}$, total carbon and nitrogen, $\mathrm{CaCO}_{3}, \mathrm{CEC}$ and $\mathrm{pH}$. Rooting depth was determined from observations of auger holes. Soil structure was observed on soil profiles to a depth of $40 \mathrm{~cm}$, using the method proposed by Gautronneau and Manichon (1987).

Manure: In the second year, a 500-g sample of fresh organic manure was analysed by the INRA laboratory in Arras to determine total nitrogen and carbon content and mineral nitrogen content. From these data and from the amount of manure applied we calculated organic and mineral nitrogen availability in the soil, based on these measurements and the amount of manure spread (organic and mineral) (Tab. I).

Weeds: Weed infestations were assessed on the microplots used for plant sampling, on the same dates. We identified species present and counted the number of plants of each species. We determined total aerial dry biomass of all weeds and total nitrogen content of the aerial parts of the plant for each sample (Dumas method). Two indicators of weed competition were calculated: (1) the relative weed biomass ratio $=$ DM weeds/(DM weeds + DM crop), where DM is Dry Matter as used by Lutman et al. (1996); and (2) the relative weed nitrogen ratio $=\mathrm{QN}$ weeds $/(\mathrm{QN}$ weeds $+\mathrm{QN}$ crop $)$, where $\mathrm{QN}$ is Quantity of Nitrogen in the plants. Other indicators included weed species, density of each species, total density of weeds and the type of weed with the highest density. Weeds were classified into types on the basis of three criteria: monocotyledon or dicotyledon, emergence period and height relative to oilseed rape. Seven types of weeds were identified depending on height relative to oilseed rape and period of emergence, similar to Primot et al. (2005).

Pests and diseases: We estimated crop damage due to pests and diseases in samples of 15 randomly collected plants per microplot. In autumn, monitoring focused on aphids, larvae of the root maggot (Delia radicum) and cabbage stem flea beetle (Psylliodes chrysocephala). In late winter, we counted the number of plants on which larvae of cabbage winter stem weevils (Ceutorhynchus picitarsis) were present and, at flowering, we counted the number of plants on which larvae of rape stem weevil (Ceutorhynchus napi) were present. Two indicators were used for the pollen beetle: the proportion of plants with larvae and the proportion of short peduncles without pods, commonly known as 'blind stalks'. At flowering, we determined the proportion of plants with pollen beetle larvae by dissecting each bud and flower of 10 plants randomly chosen from the same microplots as used for the other measurements. At the pod-filling stage, we estimated crop damage caused by spring insects. We counted the number of blind stalks on 10 randomly sampled plants per microplot. This measurement provided information about bud abortion linked to the incidence of pollen beetle damage (CETIOM, 1994). For pod midges and seed weevils, we counted, at the pod-filling stage, the number of pods that had turned yellow and were open at the base of the peduncle on a sample of 10 plants. Stem canker (Leptosphaeria maculans) damage was estimated at the pod-filling stage and a score from 1 to 6 was attributed according to the degree of rot on a collar cut (Aubertot et al., 2004). The occurrence of Leptosphaeria maculans in autumn was assessed by counting the number of plants with at least one leaf lesion. The incidence of other diseases, such as powdery mildew, was also determined in autumn and the incidence of Sclerotinia at the G4 stage: we determined the number of plants with at least one leaf lesion in autumn or with at least one stem lesion at the $\mathrm{G} 4$ stage.

Weather conditions: For each field, the nearest meteorological station from either the Meteo France network or the INRA network was chosen. Daily global radiation, temperature, Penman Potential Evapotranspiration (PPET) and rain were recorded. The number of days without rain and the number of days with minimum temperature below $0{ }^{\circ} \mathrm{C}$ were calculated for each field for four periods of development: sowing - early winter; early winter-late winter; late winter-flowering; flowering-harvest. In order to have an indicator of water stress, we calculated the sum of the daily differences between rain and ETPP.

\subsection{Statistical analysis}

We assumed a normal error distribution for continuous variables such as dry biomass and applied standard analysis of variance procedures. Proportions, such as the proportion of plants attacked by rape stem weevil, were analysed after an $\arcsin \sqrt{ }$ transformation to stabilise variance between groups. The relationships between yield, yield components and nitrogen status were determined by linear regression. A multiple linear regression procedure was used to describe yield components as a linear combination of the various indicators of limiting factors. A number of indicators of limiting factors were found to be correlated: crop biomass, nitrogen uptake by weeds or the crop and relative weed biomass or nitrogen ratio. These variables were therefore not included in the same model. Parsimonious models retained only factors for which $\mathrm{F}$ values were significant at the 0.1 level using a stepwise procedure. All analyses were done in $\mathrm{S}+$.

\section{RESULTS AND DISCUSSION}

\subsection{Variations in yield and yield components}

Yield was highly variable (range $0.14-2.67$ t.ha $^{-1}$, mean of 1.19 t.ha $^{-1}$ ) in this network of farmers' fields. Yields were highest in North 1 and gross margins for the highest yields were similar to those for organic wheat, which may be considered to perform well. Yields were lowest in Bourgogne and highest in the south of France (Fig. 2). The key question therefore relates to why yields are so low in some fields, especially as farmers obtaining such yields often decide not to continue organic oilseed rape production. Most of the farmers in this network had little experience of organic farming. Most previously grew oilseed rape in a conventional system and had little modified their cultural practices. 


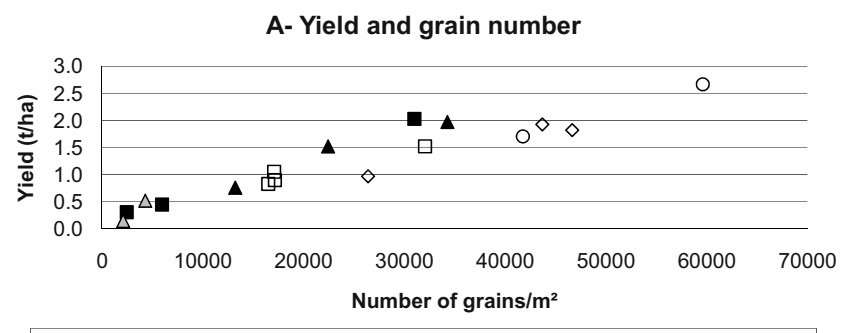

$\Delta$ North1(2002) —Center2002 $\Delta$ North2(2002) OSouth1(2001) $\square$ Center2001 $\diamond$ South2(2001)

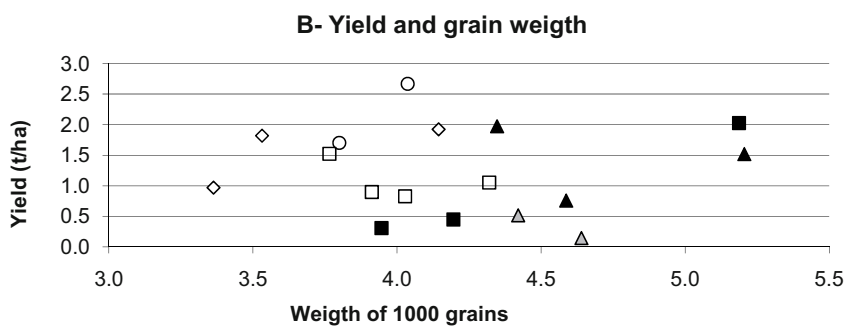

Figure 2. Relationship between yield and its components (A): number of grains $/ \mathrm{m}^{2}$ and (B): weight per grain. One point represents the mean of the two plots for yield measurements. White points and dashed regression line represent results for the first year. Black points and solid regression line represent results for the second year.

In both years, yield depended more strongly on the number of grains. $\mathrm{m}^{-2}\left(P<0.001\right.$ and $\left.\mathrm{r}^{2}=0.97\right)$ than on thousandgrain weight (Fig. 2A). In both years, the yield components' number of branches. $\mathrm{m}^{-2}$, number of flowers. $\mathrm{m}^{-2}$, number of pods. $\mathrm{m}^{-2}$ and number of grains. $\mathrm{m}^{-2}$ were highly correlated $\left(\min r^{2}=0.80\right.$ and $\max r^{2}=0.94$; data not illustrated). This result indicates that the limiting factors affecting yield occurred mainly during the development of grain number. In both years, the high correlations between the yield components suggested that the variations in the number of grains were related to the variations in the number of branches, which indicates very early limiting factors (before branching).

\subsection{Characteristics of the environmental status and biotic limiting factors}

\subsubsection{Weather over the two years and in the various regions}

Weather conditions varied with location, with particularly large differences between the center and the south of France. Climatic conditions were similar in North 2 and central regions in the second year. Winter temperatures fell below $0{ }^{\circ} \mathrm{C}$ on 14 days in the south: in contrast, they were sub-zero on 73 days in the center and 68 days in North 2. Frosts may have occurred during flowering in North 2 and the center. The average temperature in the second year was lower than in the first in the center of France, with lower minimum temperatures $\left(-15^{\circ} \mathrm{C}\right.$ in the second year and $-10^{\circ} \mathrm{C}$ in the first). The water stress was also more severe in 2002 than in 2001 in this region.

\subsubsection{Nitrogen nutrition}

The nitrogen nutrition index (NNI) varied between fields, ranging from 0.40 to 1.2 in early winter (Tab. II), and tended to increase over the winter, reaching 0.6 to 1.3 in late winter. Thereafter, it drastically decreased until flowering, ranging from 0.2 to 0.75 . In early winter, 3 of 19 fields had a NNI below 0.5 , whereas during flowering, 15 of the 19 fields had a NNI below 0.5 . High levels of nitrogen uptake by the crop were often associated with high NNI in early winter, except for fields N02 and E02 (significant regression between NNI and nitrogen uptake; $P<0.01 ; \mathrm{r}^{2}=0.28$ with these two fields and 0.67 without these fields). The mineral nitrogen content of the soil measured in early winter exceeded $60 \mathrm{~kg} \cdot \mathrm{ha}^{-1}$ in only one case (113 kg.ha ${ }^{-1}$ in E02). The mean mineral $\mathrm{N}$ content of the network did not vary significantly over the crop cycle in a given field: $44 \mathrm{~kg} \cdot \mathrm{ha}^{-1}$ in early winter, $47 \mathrm{~kg} \cdot \mathrm{ha}^{-1}$ in late winter and $46 \mathrm{~kg}$. ha ${ }^{-1}$ during flowering (Tab. II). Nitrogen uptake in weeds was variable, ranging from $0.2 \mathrm{~kg} \cdot \mathrm{ha}^{-1}$ to $50 \mathrm{~kg} \cdot \mathrm{ha}^{-1}$, and tended to be higher if the levels of nitrogen absorption by the crop were low (data not shown). However, the relationship between nitrogen uptake by weeds and by the crop depended on weed type. For example, in the fields E'02 (center 2002) and M02 (North 2), nitrogen uptake in the crop reached $95 \mathrm{~kg} \cdot \mathrm{ha}^{-1}$, while nitrogen in weeds reached $3 \mathrm{~kg} \cdot \mathrm{ha}^{-1}$ for field M02 and $17 \mathrm{~kg} \cdot \mathrm{ha}^{-1}$ in field E'02. These two fields differed mainly in the type of weeds (Tab. III).

\subsubsection{Weed competition}

Weed density was highly variable (from 18 to 544 plants. $\mathrm{m}^{-2}$, Tab. II). In 5 of the 19 fields the main weeds in early winter were volunteers of the preceding wheat or barley crop. In most of these cases, the density of volunteers did not decrease (Tab. III). Geranium dissectum occurred in only one field, whereas Alopercurus myosuroides, Sonchus asper and brassicas such as Sinapis arvensis and Raphanus raphanistrum occurred in at least two fields. Alopercurus myosuroides was the weed with the highest density. In our study, the fields with the lowest yields contained cereal volunteers (type 1 of our classification, detailed in Primot et al., 2005), Galium aparine (type 5), Alopecurus myosuroides (type 2) and Sinapis, wild radish (type 7). The field with the highest yields contained Mercurialis annua (type 3). Lutman et al. (1995) have pointed out competitive and not competitive weeds. The authors showed that the types 5 and 7 were rather competitive and that type 6 was not competitive, which is partly in accordance with our study.

The weed biomass ratio was not necessarily high in fields with high weed density: for example, in fields F01, I01, K01 and L02, weed density varied from 118 to 128 plants. $\mathrm{m}^{-2}$ regardless of the measurement period, whereas the relative weed biomass ratio varied from 0.05 to 0.2 . It can also be noticed that the weed biomass ratio in early winter was related to NNI at the flowering stage (data not illustrated; $r^{2}=0.68$ ).

These different indicators of weed competition (the relative ratio of weed dry biomass, the relative ratio of weed nitrogen and weed density, and weed density by type) must be 
Table II. Distribution of nitrogen status of the crop (NNI), weed density, biomass nitrogen and weed dry biomass, and disease incidence and gravity in three different periods.

\begin{tabular}{|c|c|c|c|c|}
\hline period & & $\min$ & mean & $\max$ \\
\hline \multirow[t]{7}{*}{ Early winter } & NNI & 0.4 & 0.8 & 1.2 \\
\hline & nitrogen in soil $\left(\mathrm{kg} \cdot \mathrm{ha}^{-1}\right)$ & 16.0 & 44.3 & 113.5 \\
\hline & weed biomass $\left(\right.$ t.ha $\left.^{-1}\right)$ & 0.0 & 0.4 & 1.3 \\
\hline & weed density (plant. $\mathrm{m}^{-2}$ ) & 21.0 & 102.5 & 357.3 \\
\hline & weed ratio of biomass & 0.0 & 0.2 & 0.6 \\
\hline & nitrogen accumulated in weeds $\left(\mathrm{kg} \cdot \mathrm{ha}^{-1}\right)$ & 0.20 & 11.58 & 47.00 \\
\hline & proportion of plants with phoma lesion & 0.00 & 0.18 & 1.00 \\
\hline \multirow[t]{6}{*}{ Late winter } & NNI & 0.6 & 0.9 & 1.3 \\
\hline & nitrogen in soil $\left(\mathrm{kg} \cdot \mathrm{ha}^{-1}\right)$ & 12.3 & 47.8 & 100.5 \\
\hline & weed biomass $\left(\mathrm{t}^{-h^{-1}}\right)^{-}$ & 0.0 & 0.4 & 1.6 \\
\hline & weed density (plant.m ${ }^{-2)}$ & 10.0 & 120.4 & 544.0 \\
\hline & weed ratio of biomass & 0.0 & 0.2 & 0.7 \\
\hline & nitrogen accumulated in weeds $\left(\mathrm{kg} \cdot \mathrm{ha}^{-1}\right)$ & 0.00 & 9.94 & 28.12 \\
\hline \multirow[t]{8}{*}{ Flowering } & NNI & 0.2 & 0.4 & 0.7 \\
\hline & nitrogen in soil $\left(\mathrm{kg} \cdot \mathrm{ha}^{-1}\right)$ & 16.7 & 46.6 & 101.0 \\
\hline & weed biomass $\left(\right.$ t.ha $\left.^{-1}\right)$ & 0.1 & 0.9 & 2.7 \\
\hline & weed density (plant. $\mathrm{m}^{-2}$ ) & 18.0 & 83.1 & 295.5 \\
\hline & weed ratio of biomass & 0.0 & 0.2 & 0.8 \\
\hline & nitrogen accumulated in weeds $\left(\mathrm{kg} \cdot \mathrm{ha}^{-1}\right)$ & 0.87 & 14.5 & 50.7 \\
\hline & proportion of plants with sclerotinia & 0.00 & 0.02 & 1.00 \\
\hline & gravity score of stem canker & 0.00 & 0.7 & 2.9 \\
\hline
\end{tabular}

discussed a little. The first of these indicators has been used to assess weed competition in previous studies (Lutman et al., 1996, 2000). Lutman et al. (2000) showed that yield loss predictions based on relative weed dry weight were more accurate than those based on weed density. The relative ratio of weed nitrogen has never been used before and serves as an indicator of competition with weeds for nitrogen.

\subsubsection{Insect damage and disease}

The incidence of cabbage stem flea beetle was very variable and depended on the region, with levels of attack particularly high in the south (Tab. IV; 60 and 100\% of plants with at least one larva). In contrast, no cabbage stem flea beetle was detected in the north. Root maggot attacks were systematically more severe in the center than in other regions: in this region, we observed symptoms of root maggot attacks on more than $20 \%$ of plants in both years (Tab. IV). Cabbage stem flea beetle and root maggot were the most frequently detected autumn insects at field level.

The rape stem weevil (C. napi) was the most frequently detected in 10 of the 19 fields, with more than $40 \%$ of plants attacked (Tab. IV). In both years, attacks were most severe in the center (in 2 of 4 fields, $60 \%$ of plants had symptoms in 2001 while in 2002, all fields were attacked and $100 \%$ of plants displayed symptoms). Severe attack of aphids was observed only in one field - C01 - in 2001. Pollen beetles and pod midges caused more severe damage in the second year than in the first. It was the case in the north and center of France, where more than $30 \%$ of flowers aborted because of pollen beetle attacks in five of the six fields. In 2001, the number of plants with at least one pollen beetle larva exceeded $50 \%$ in eight of 10 fields (data not shown). However, the proportion of flowers aborted due to pollen beetle attack did not exceed $25 \%$.

Disease incidence was very low: stem canker (Leptosphaeria maculans) attacked $20 \%$ of plants in the first year and $50 \%$ in the second year, but the disease score did not exceed 2.9 out of 9 (Tab. II).

\subsubsection{Soil structure}

In most of the fields studied, with the notable exception of field Q02, the soil was not compacted and the regular density of roots over the three soil layers demonstrated that soil structure did not affect the absorption of minerals and water by the crop. In contrast, the soil in field Q02 had a coarse structure, with a high proportion (100\% and $70 \%$ of soil volume in the first two layers, respectively) of highly compacted clods. This structure strongly impeded root growth and functioning.

\subsection{Identification of the limiting factors of crop biomass, yield components and yield}

We carried out several stepwise regression analyses on crop biomass and yield components at each stage: crop biomass in early and late winter, number of flowers. $\mathrm{m}^{-2}$ at flowering, number of branches. $\mathrm{m}^{-2}$ and number of pods. $\mathrm{m}^{-2}$ at the pod-filling stage, and number of grains. $\mathrm{m}^{-2}$ at harvest. Relationships between these variables and possible limitations due to pests and climate during the crop cycle were investigated (Fig. 3). This method permitted us to identify and rank the major limiting factors occurring in an organic system, which has never been done. 
Table III. Main weeds observed (common name and Latin name in each farm field in early winter and at flowering).

\begin{tabular}{|c|c|c|}
\hline \multirow[b]{2}{*}{ Farm field } & Early winter & Flowering (F2) \\
\hline & Main weeds & Main weeds \\
\hline \multirow[t]{2}{*}{ A01 } & Meadow cranesbill & Meadow cranesbill \\
\hline & Geranium dissectum & Geranium dissectum \\
\hline \multirow[t]{2}{*}{ B01 } & Common sow thistle & Groundsel \\
\hline & Sonchus asper & Senecio vulgaris \\
\hline \multirow[t]{2}{*}{ B02 } & Common sowthistle & Common field speedwell \\
\hline & Sonchus asper & Veronica arvensis \\
\hline $\mathrm{C} 01$ & Barley & Barley \\
\hline D01 & Barley & Barley \\
\hline E01 & Wheat & Wheat \\
\hline E02 & Wheat & Wheat \\
\hline \multirow[t]{2}{*}{ E’02 } & Wheat, cleavers & Cleavers \\
\hline & Galium aparine & Galium aparine \\
\hline \multirow[t]{2}{*}{ F01 } & Annual mercury & Red shank \\
\hline & Mercurialis annua & Polygonum persicaria \\
\hline \multirow[t]{2}{*}{ G01 } & Annual mercury & Red poppy \\
\hline & Mercurialis anпиа & Papaver rhoeas \\
\hline \multirow[t]{2}{*}{ I01 } & Wild chamomile & Violet \\
\hline & Matricaria recutita & Viola arvensis \\
\hline \multirow[t]{2}{*}{ J01 } & Chick weed & Violet \\
\hline & Stellaria media & Viola arvensis \\
\hline \multirow[t]{2}{*}{ K01 } & Common foxtail & Lady's mantle \\
\hline & Alopecurus myosuroides & Aphanes arvensis \\
\hline \multirow[t]{2}{*}{ L02 } & Perennial ryegrass & Perennial ryegrass \\
\hline & Lolium perenne & Lolium perenne \\
\hline \multirow[t]{2}{*}{ M02 } & Red poppy & Red poppy \\
\hline & Papaver rhoeas & Papaver rhoeas \\
\hline \multirow[t]{2}{*}{ N02 } & Wild mustard & Common foxtail \\
\hline & Sinapis arvensis & Alopecurus myosuroides \\
\hline \multirow[t]{2}{*}{$\mathrm{O} 02$} & Common foxtail & White clover \\
\hline & $\begin{array}{c}\text { Alopecurus myosuroides } \\
\text { White clover }\end{array}$ & \\
\hline \multirow[t]{4}{*}{ P02 } & Wild radish & Wild chamomile \\
\hline & Raphanus raphanistrum, & Matricaria recutita \\
\hline & Common field speedwell & Common foxtail \\
\hline & Veronica arvensis & Alopecurus myosuroides \\
\hline \multirow[t]{2}{*}{ Q02 } & Common foxtail & Common foxtail \\
\hline & Alopecurus myosuroides & Alopecurus myosuroides \\
\hline
\end{tabular}

\subsubsection{Climatic factors}

In early and late winter, the proportion of variance in crop biomass accounted for by climatic conditions (number of cold days, water stress and number of days without rain) did not exceed $10 \%$ in early winter and 5\% in late winter. During flowering, while the number of flowers. $\mathrm{m}^{-2}$ was slightly affected by the number of cold days, the number of pods. $\mathrm{m}^{-2}$ was affected by water availability for the plant: soil depth and number of days without rain (Fig. 3A, B).

\subsubsection{Insect damage and disease}

In early and late winter the proportion of the variance accounted for by flea beetles did not exceed $10 \%$ in early winter and cabbage stem weevils did not appear to be significant in late winter. The percentage of plants with at least one phoma lesion on leaves and NNI in early winter were significant in regression analysis (probability not shown) but the proportion of the variance accounted for by this factor was small (Fig. 3A). During flowering, the only pest accounting for more than 5\% of the variance throughout the crop cycle was rape stem weevil on the number of branches and pollen beetle on the number of pods. $\mathrm{m}^{-2}$, whereas the percentage of plants with sclerotinia and the gravity score of stem canker did not account for more than $1.5 \%$ of the variance (Fig. 3C). Very few studies have reported the impact of pollen beetles on yield losses (Nilsson, 1994), mainly because of the capability of the crop to compensate for the abortion of some flowers. It may explain why the pollen beetle was not selected to explain the number of grains. $\mathrm{m}^{-2}$ (Fig. 3D).

\subsubsection{Weed competition and nitrogen}

In early and late winter, total crop biomass was significantly affected by weeds. The relative weed nitrogen ratio, weed biomass, weed density and the main type of weed were identified as significant in stepwise regressions. All indicators of weed competition had a negative coefficient in the linear regression (data not shown). These indicators of weed competition together accounted for $38.9 \%$ (Fig. 3A) of the variance in early winter and $40 \%$ in late winter. The type of weed, characterised in terms of period of emergence and height with respect to the crop, affected the various yield components and had a significant effect early in the crop cycle. Various studies on the competitive effects of volunteer cereals on oilseed rape demonstrated the importance of crop vigour in determining crop competitiveness (Lutman and Dixon, 1991). The results obtained in fields C01, D01, E02 and E'02, which had high volunteer densities, confirmed these results and were in accordance with Lutman et al. (1995).

At flowering and before harvest, nitrogen and weeds accounted for significant proportions of the variation in numbers of branches, flowers and pods. $\mathrm{m}^{-2}$ (Fig. 3B, C). Plant nitrogen uptake accounted for an increasing proportion of variation: $9 \%$ for the number of branches. $\mathrm{m}^{-2}, 29.5 \%$ for the number of flowers. $\mathrm{m}^{-2}$ and $58 \%$ for the number of pods. $\mathrm{m}^{-2}$. However, the hierarchy of these limiting factors (nitrogen and weeds) in those periods differed slightly from that before the winter. Indeed, nitrogen status of the crop at flowering largely accounted for the numbers of branches and of flowers per $\mathrm{m}^{2}$, whereas weed dry biomass and nitrogen uptake by weeds accounted for no more than $2 \%$ of the variance of flowers. $\mathrm{m}^{-2}$ and $15 \%$ of variance of pods. $\mathrm{m}^{-2}$. In both years, grain number. $\mathrm{m}^{-2}$ was strongly correlated with the amount of nitrogen absorbed in early winter or at the pod-filling stage (data not shown).

The two main factors affecting growth and yield components - crop nitrogen status and the weed population - were interdependent. Indeed, if NNI in early winter was high (greater than 0.7), then the weed biomass ratio at flowering tended to be low. In contrast, if NNI in early winter was low (less than 0.7 ), then the weed biomass ratio at flowering tended to be high. Figure 4 illustrates this significant relationship between 
Table IV. Number of fields in which damage due to the pest cited occurred. Presence of or damage due to Psylliodes chrysocephala L. and Delia radicum L. was measured in early winter on a sample of 90 plants (15*6 microplots). Presence of or damage due to Ceuthorhynchus picitarsis was measured in late winter and the presence of or damage due to Ceuthorhynchus napi + Brevicoryne brassicae L. was measured at flowering on a sample of 90 plants. For Meligethe aeneus, at the pod-filling stage, the number of blind stalks on 10 randomly sampled plants per microplot was counted. For pod midges and seed weevils, we counted, at the pod-filling stage, the number of pods that had turned yellow and were open at the base of the peduncle on a sample of 10 plants.

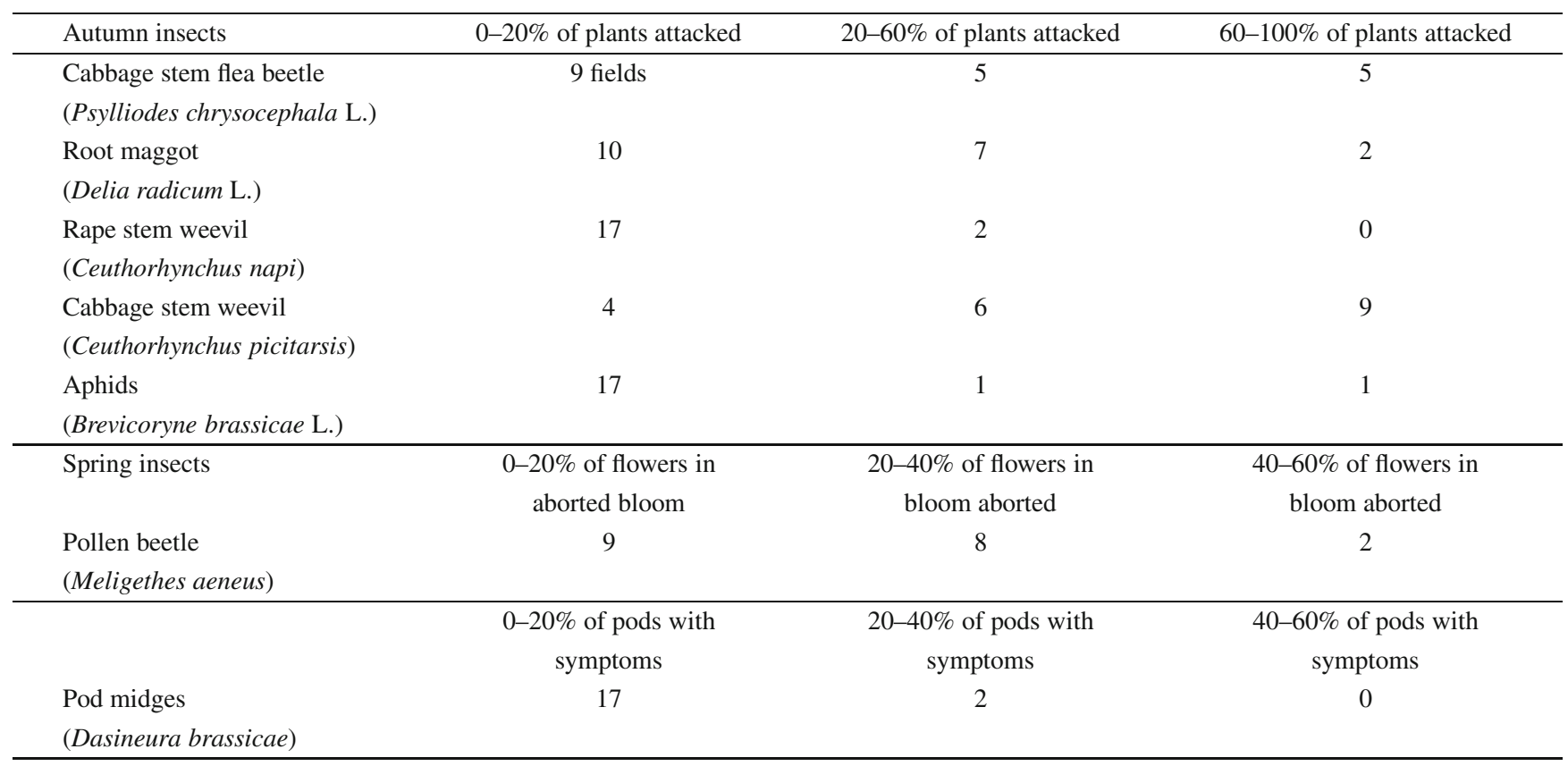

the amount of nitrogen accumulated in the crop during autumn and the weed dry biomass. Primot et al. (2005) pointed out that the threshold of weed biomass that could induce yield loss was $0.15 \mathrm{t}^{\mathrm{h} \mathrm{h}^{-1}}$. In our study, before this value of dry weed biomass, the mean value of nitrogen in crops was $98 \mathrm{~kg} \cdot \mathrm{ha}^{-1}$. Therefore, considering that oilseed rape is able to trap high amounts of nitrogen in soil, it could be concluded that the minimum amount of nitrogen that farmers should spread before sowing, in order to ensure that crops compete with weeds, is around $100 \mathrm{~kg} / \mathrm{ha}$.

If we detail the results on weed competition, it can be mentioned that the relative ratio of weed nitrogen before spring had a high and significant effect, suggesting that competition between crops and weeds for nitrogen has an impact on crop growth. This is consistent with the low values of the nitrogen nutrition index $(<0.7)$ obtained in half of the fields in early winter and in almost all fields at flowering. In our results crops with nitrogen nutrition index values greater than 0.7 were in competition with a lower biomass of weeds, even if weed densities were high. Ferré et al. (2000) and Dejoux et al. (1999) found that high levels of nitrogen uptake during autumn were associated with a large increase in biomass and leaf area index, resulting in a decrease in weed growth and density. Our results demonstrate that this specific trait is important in organic farming. High levels of nitrogen uptake in the autumn make the crop more competitive against weeds throughout the crop cycle, due to an early smothering effect, resulting in an early decrease in weed density and long-term positive effects on crop growth, with no weed seed production, as was observed by Ferré et al. (2000). Moreover, the proportion of the variance accounted for by weed indicators was lower for the number of flowers and grains. $\mathrm{m}^{-2}$ than for early biomass or the number of branches. This suggests that the critical period of competition for the crop occurred very early in the crop cycle, essentially before winter. Welsh et al. (1999) confirmed that the control of weed emergence in organic wheat crops was the most important at the beginning of the crop cycle.

The results in early and late winter on the effects of weed competition on the number of branches. $\mathrm{m}^{-2}$ also showed that competition with weeds explained the results for branching, but that the uptake of nitrogen of the crop was more relevant in spring. Those results suggested that competition with weeds before spring resulted in low nitrogen availability for the crop during autumn, but also during the period of re-growth and branching, which might have had consequences on the number of flowers (Colnenne et al., 1999; Maillet, 1992), and consequently on the number of grains. $\mathrm{m}^{-2}$.

All these results permitted us to conclude two main results: (i) during autumn and winter, weed competition (weed biomass, the weed or nitrogen ratio, and weed density) and nitrogen uptake were the main factors accounting for the high variability in oilseed rape biomass and the number of branches. $\mathrm{m}^{-2}$ and thereafter the number of grains; and (ii) despite the high values of insect occurrence in some fields (Tab. IV), they explained the yield loss in low proportion except for pollen beetle and rape stem weevil. In conventional 

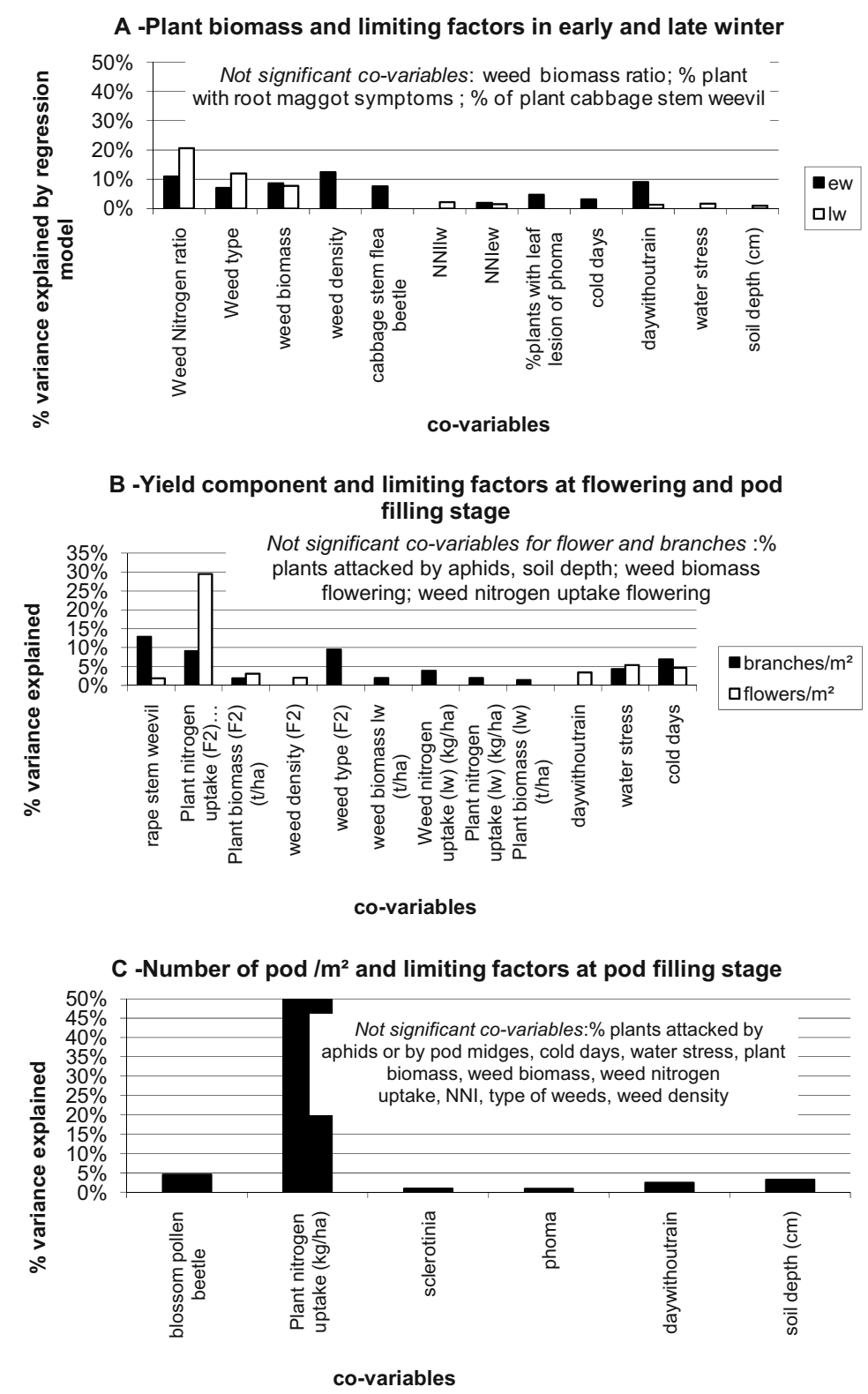

D -Number of Grains and limiting factors

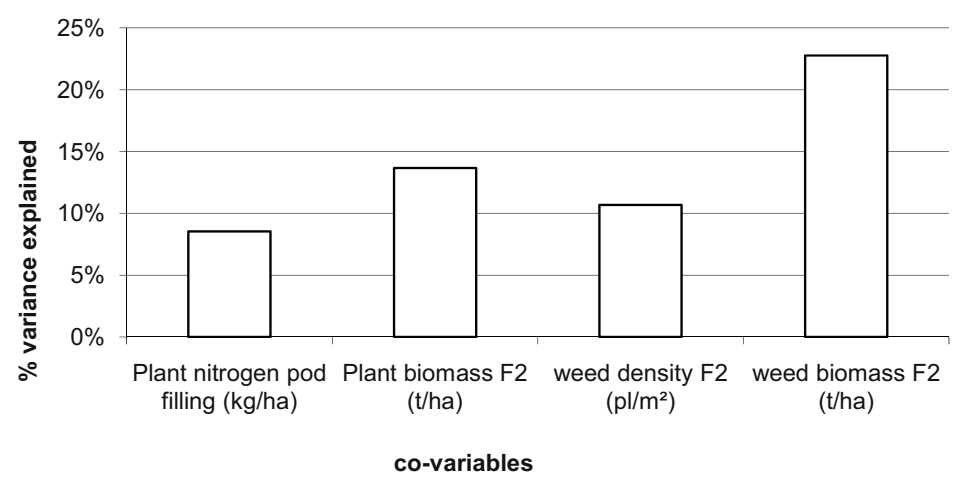

Figure 3. Results of stepwise regressions on the various yield components throughout the crop cycle: in early and late winter (A) during flowering and the pod-filling stage (B) or for the number of pods. $\mathrm{m}^{-2}(\mathrm{C})$ or for the number of grains. $\mathrm{m}^{-2}(\mathrm{D})$. Ew and lw mean early winter and late winter. F2 corresponds to the flowering stage. NNI is the nitrogen nutrition index. 


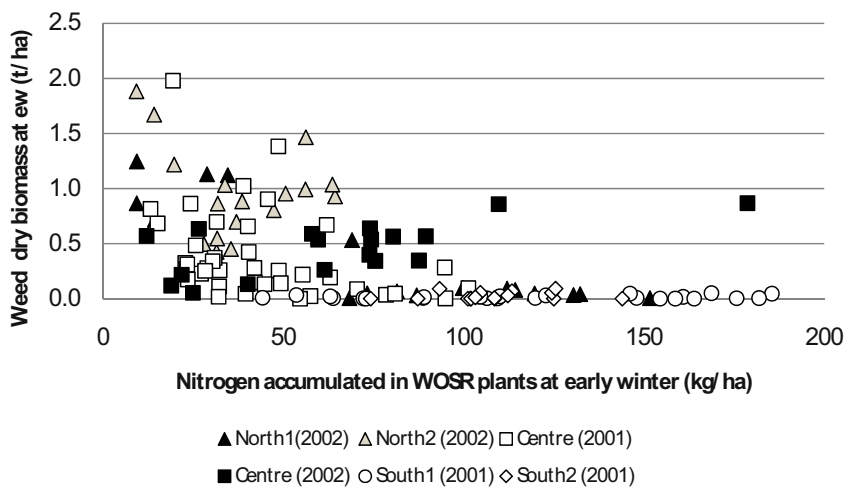

Figure 4. Relationship between nitrogen accumulated in plants and nitrogen accumulated in weeds for each region in early and late winter and at flowering. One point represents the result of a microplot.

systems, diseases, such as Phoma and Sclerotinia, are often responsible for high yield losses (Merrien and Pouzet, 1988), which is rather different from organic systems.

\subsection{Effect of crop management and environmental conditions on limiting factors}

Since weed competition and nitrogen appeared in the previous section to be the main limiting factors of yield, we investigated here the effects of crop management on the indicators of weed competition, and nitrogen uptake and deficiencies.

\subsubsection{Date and density of sowing, soil tillage and weeding}

The various indicators of weed competition in early winter were largely accounted for by plant density, the previous crop or soil management before sowing, and in a lower proportion, sowing date (Tab. V). The date of sowing had a significant effect only on the weed dry biomass ratio (Tab. V). This effect has been shown to have a major effect on plant growth at early stages (Dejoux et al., 2003) and on the competitiveness of the crop (Whytock, 1993; Ferré et al., 2000). There is an interaction between sowing date and soil nitrogen availability on plant growth during autumn (Dejoux et al., 1999; Ferré et al., 2000). Those studies may explain the sole effect of sowing date on the weed dry biomass ratio and may account for the diverse results observed in our field network. The analysis of covariance (Tab. V) also showed that nitrogen availability in the soil at sowing may have affected weed density. Increases in soil nitrogen content tended to decrease weed biomass, but this relationship may have depended on weed type and density (Tab. III: see Fields E'02 (center 2002) and M02 (North 2); Fig. 3A). Our experimental design did not allow us to test whether there was an interaction between weed type and nitrogen availability, but this is likely to have been the case and has already been observed in wheat (Jørnsgård et al., 1996), potato (Delden et al., 2002) and sugar beet (Paolini et al., 1999).
The effects of sowing date and nitrogen availability on weed competition are consistent with the similar effects on crop nitrogen deficiencies and nitrogen content in soil. Analysis of covariance showed that sowing date, soil management and the quantity of organic manure spread were correlated with the NNI, nitrogen uptake by plants and soil nitrogen content three weeks after sowing (Tab. V): early sowing date, high organic manure application and ploughing were related to high crop NNI, high aerial crop biomass and low nitrogen uptake by weeds.

Oilseed rape plant density had a significant effect on dry weed biomass in early winter, but this effect did not persist until flowering (data not shown). This was not observed in a previous diagnosis study on conventional oilseed rape (Dejoux, 1999), which may be due to the higher weed density and larger range of weed types in our study. Moreover, the effect of crop density might also interact with the type and the density of the weeds in competition, as it was observed in wheat (Angonin et al., 1996).

Although few studies have dealt with the effect of soil management on weed emergence in oilseed rape, shallow tillage has been shown to result in a larger weed seed emergence in corn and winter wheat crops than ploughing (Barberi and Lo Cascio, 2001; Feldman et al., 1997). Our results confirm these studies. Moreover, the effect of soil tillage on the preceding crops could have consequences on soil structure. It was the case in field Q02, which exhibited a compacted structure, which may explain the poor uptake of available nitrogen by the crop in this field. The massive, compact soil structure observed in field Q02 strongly impeded root growth and functioning.

Mechanical weeding was significantly related to low weed biomass and a low dry weed biomass ratio, but was not related to weed density.

Rape stem weevil was selected in stepwise regressions, and contributed to high variance. Pollen beetle had a major effect on some fields: the incidence of this insect on the three fields in the North 2 of France varied from $30 \%$ to $60 \%$ of blooming flowers aborted. A previous study (Valantin-Morison et al., 2007) demonstrated that crop management, including sowing date, soil nitrogen and plant density in particular, has a significant effect on those pests' occurrence. This study also shows the great importance of landscape structures for pests' attack.

\subsubsection{Organic fertilisation and crop rotation}

In our study, no organic fertiliser was applied during spring, while organic manure was sometimes spread before sowing. It resulted in high nitrogen deficiencies in spring in many fields. According to Colnenne et al. (2002), autumn nitrogen deficiencies generally have no effect on yield and the grain number but nitrogen deficiencies during spring affect the number of flowers (Colnenne et al., 1999). The absence of spring fertilisation in our network could therefore explain the severe impact of autumn and spring deficiencies on yield components (Fig. 3). This absence of spring fertilisation may be due to the high cost of the off-farm nitrogen fertilisers (such as feather meal or guano) generally used for wheat fertilisation (David 
Table V. Probability (\% of variance accounted for) and coefficient of the regression obtained in a co-ANOVA analysis concerning the effects of cultural practices and environment on various indicators of weed competition in early winter and on the nitrogen status of the crop in early winter. Coefficients are not detailed for qualitative variables such as previous crop and type of organic manure.

\begin{tabular}{|c|c|c|c|}
\hline $\begin{array}{l}\text { Environmental status or } \\
\text { cultural practices accounting } \\
\text { for weed indicators }\end{array}$ & $\begin{array}{l}\text { Weed density } \\
\qquad\left(\mathrm{pl} / \mathrm{m}^{2}\right) \\
\mathrm{R}^{2}=0.27\end{array}$ & $\begin{array}{l}\text { Weed biomass } \\
\qquad \begin{array}{c}(\mathrm{t} / \mathrm{ha}) \\
\mathrm{R}^{2}=0.35\end{array}\end{array}$ & $\begin{array}{l}\text { Ratio of weed biomass } \\
\qquad \mathrm{R}^{2}=0.62\end{array}$ \\
\hline Amount of nitrogen in soil & 0.02 & 0.04 & 0.000 \\
\hline \multirow[t]{2}{*}{3 weeks after sowing $(\mathrm{kg} / \mathrm{ha})$} & $(3.1 \%)$ & $(2.1 \%)$ & $(6.2 \%)$ \\
\hline & -0.77 & -0.0024 & -0.0029 \\
\hline \multirow[t]{2}{*}{ Plant density (plants $/ \mathrm{m}^{2}$ ) } & $0.06(2.1 \%)$ & $0.09(14.9 \%)$ & $0.034(1.4 \%)$ \\
\hline & -1.16 & -0.0037 & -0.0025 \\
\hline \multirow[t]{3}{*}{ Sowing date (Julian days) } & 0.73 & 0.47 & 0.000 \\
\hline & & & $(39 \%)$ \\
\hline & & & 0.0049 \\
\hline \multirow[t]{2}{*}{ Previous crop } & 0.000 & 0.000 & 0.000 \\
\hline & $(10.9 \%)$ & $(16.5 \%)$ & $(6.4 \%)$ \\
\hline Soil management (encoded as & 0.00 & 0.000 & 0.000 \\
\hline shallow tillage 0 and & $(9.6 \%)$ & $(8.2 \%)$ & $(7.4 \%)$ \\
\hline ploughing 1) & -0.98 & -0.0034 & -0.0023 \\
\hline Mechanical weeding & 0.13 & 0.0 & 0.032 \\
\hline (utilisation of weed harrow or & $(1.3 \%)$ & $(7.1 \%)$ & $(1.4 \%)$ \\
\hline \multirow[t]{4}{*}{ weed hoe-1- or neither-0-) } & -26 & 0.23 & -0.07 \\
\hline & NNI & Nitrogen uptake & Nitrogen in soil three \\
\hline & & in plants $(\mathrm{kg} / \mathrm{ha})$ & weeks after sowing $(\mathrm{kg} / \mathrm{ha})$ \\
\hline & $\mathrm{R}^{2}=0.54$ & $\mathrm{R}^{2}=0.54$ & $\mathrm{R}^{2}=0.21$ \\
\hline \multirow[t]{3}{*}{ Sowing date (Julian day) } & 0.00 & 0.07 & 0.002 \\
\hline & $(41 \%)$ & $(1.2 \%)$ & $(5.8 \%)$ \\
\hline & 0.013 & 0.42 & 2.5 \\
\hline \multirow[t]{3}{*}{ Soil depth (cm) } & 0.00 & 0.00 & 0.94 \\
\hline & $(7.7 \%)$ & $(14 \%)$ & \\
\hline & -0.096 & -23.7 & \\
\hline Soil management & 0.00 & 0.00 & 0.49 \\
\hline (encoded as shallow tillage 0 & $(5.7 \%)$ & $(24 \%)$ & \\
\hline and ploughing 1) & 0.130 & 48.0 & \\
\hline Quantity of organic manure & 0.00 & 0.00 & 0.00 \\
\hline spread before sowing $(\mathrm{t} / \mathrm{ha})$ - & $(0.08 \%)$ & $(11.5 \%)$ & $(15 \%)$ \\
\hline see Table I- & 0.0007 & 1.43 & 3.9 \\
\hline
\end{tabular}

et al., 2005). Seventeen of the 19 fields were treated with organic fertiliser in autumn. The type of organic manure used seems to be of importance: although only a small amount of organic manure was applied to fields $\mathrm{G}$ and $\mathrm{K}$, absorption by the crop in early winter was higher in these fields than in field B02. Oilseed rape is an efficient nitrate-trapping crop, particularly if sown early (Dejoux et al., 2003). Moreover, oilseed rape leaves falling in the autumn and winter can return nitrogen to the soil during spring (Dejoux et al., 2000). This may explain why organic nitrogen applied in autumn to fields F01, G01, L02, J01, M02, K02, B01 and B02 resulted in yields exceeding 1.5 t.ha $^{-1}$.

The farmers' surveys permitted us to point out that the place of oilseed rape in the crop rotation depends on the availability of organic manure, which is the main constraint of organic farmers. If organic manure is easily available on the farm or exchanges are made with mixed farms, oilseed rape is preceded by cereals (mainly wheat). In such cases, as the crop can return nitrogen to the soil, many farmers aim to replace some grain legumes, such as tick bean (Vicia faba L. var. minor Harz), by oilseed rape in the rotation or to introduce oilseed rape into a longer rotation before a winter wheat crop. If organic manure or fertiliser is not available on the farm, oilseed rape is preceded by grain legumes.

\section{CONCLUSION}

The regional agronomic diagnosis methodology, already tried and tested on several problems in conventional 
agriculture, was here adapted to a study of variation in yield in organic systems, where more numerous limiting factors could be observed. A stepwise regression procedure has been used in previous studies on the yield or on the final yield components such as number of grains and protein content (Brancourt-Hulmel et al., 1999; David et al., 2005; Le Bail and Meynard, 2003). In our study, a range of possible limiting factors throughout the crop cycle led us to use a regression procedure for different periods, using the yield components during spring and biomass during autumn as dependent variables. This type of analysis has never been done. David et al. (2005), who used the same diagnostic method on organic winter wheat, also demonstrated that weeds and nitrogen are the main limiting factors. This study also demonstrated that crop densities, type of weeds and soil tillage affect the relationship of the crop with the weeds very early in autumn. From a practical point of view, the results of this study demonstrate that it should be possible to reduce weed problems by ensuring that nitrogen availability is high at sowing and during the autumn. In the organic system, nitrogen availability constitutes a problem; this study provided a key element on the minimum amount of nitrogen that the crop should uptake to compete with the weeds during autumn. With the exception of the deleterious effects of some insects, it should be possible to increase oilseed rape yields in organic systems by limiting competition with weeds for nitrogen early in the crop cycle. Conversely to conventional farms, oilseed rape may not be cultivated in all organic farming systems. Mixed farms and farms with other sources of organic manure could easily adopt this crop as part of their rotation. Moreover, because of autumn fertilisation with organic manure, an environmental assessment of oilseed rape organic crop management should be carried out.

Acknowledgements: We are indebted to G. Grandeau, V. Tanneau, B. Fouillen, C. Soin, A. Chauveau, R. Baudoin and E. Castel for their technical help. Y. Ballanger from the Cetiom (Center technique des oléagineux métropolitains) provided helpful expertise for the diagnosis of insect damage. We would also like to thank S. Tanis-Plant for editorial advice and T. Doré for his relevant advice. Financial support for this study was provided by the INRA (CIAB) and by the CETIOM. We specially thank R. Reau, L. Quéré, C. Bonnemort and D. Chollet from the Cetiom for their help in finding financial support and in building the farmers' network.

\section{REFERENCES}

Angonin C., Caussanel J.P., Meynard J.M. (1996) Competition between winter wheat and Veronica hederifolia: influence of weed density and the amount and timing of nitrogen application, Weed Res. 36, $175-187$.

Aubertot J.N., Schott J.J., Penaud A., Brun H., Doré T. (2004) Methods for sampling and assessment in relation to the spatial pattern of phoma stem canker (Leptosphaeria maculans) in oilseed rape, Eur. J. Plant Pathol. 110, 183-192.

Bail M. le, Meynard J.M. (2003) Yield and protein concentration of spring malting barley: the effects of cropping systems in the Paris Basin (France), Agronomie 23, 13-27.

Barberi P., Lo Cascio B. (2001) Long-term tillage and crop rotation effects on weed seedbank size and composition, Weed Res. 41, $325-335$.
Bourre J.M. (1996) Développement du cerveau et acides gras polyinsaturés, Oléagineux, Corps gras, Lipides, 3, 173-178.

Brancourt-Hulmel M., Lecomte C., Meynard J.M., (1999) A diagnosis of yield-limiting factors on probe genotypes for characterizing environments in winter wheat trials, Crop Sci. 39, 1798-1808.

Cetiom (1994) Guide de l'expérimentateur.

Clark S., Klonsky K., Livingston P., Temple S. (1999) Crop-yield and economic comparisons of organic, low-input and conventional farming systems in California's Sacramento Valley, Am. J. Alternative Agr. 14, 109-121.

Colnenne C., Meynard J.M., Reau R., Roche R. (1998) Determination of a critical nitrogen dilution curve for winter oilseed rape, Ann. Bot. 81, 311-317.

Colnenne C., Roche R., Meynard J.-M. (1999) Test of the CERES-rape model for winter oilseed rape: effect of the plant nitrogen status on yield's components, 10th International rapeseed congress, Canberra, Australia, 1999/09/26-29, CD-Rom New horizons For an Old Crop.

Colnenne C., Meynard J.M., Roche R., Reau R. (2002) Effects of nitrogen deficiencies on autumnal growth of oilseed rape, Eur. J. Agron. 17, $11-28$.

Cook S.M., Smart L.E., Potting R.J.P., Bartlet E., Martin J.L., Murray D.A., Watts N.P., Williams I.H. (2002) Turnip rape (Brassica rapa) as a trap crop to protect oilseed rape (Brassica napus) from infestation by insect pests: potential and mechanisms of action, The BCPC Conference: Pests and diseases, Vol. 1, 2, Proceedings of an international conference Brighton, UK, 18-21 November 2002, pp. 569574.

Cook S.M., Murray D.A., Williams I.H. (2004) Do pollen beetles need pollen? The effect of pollen on oviposition, survival, and development of a flower-feeding herbivore, Ecol. Entomol. 29, 164-73.

David C., Jeuffroy M.H., Henning J., Meynard J.M. (2005) Yield variations of organic winter wheat: a crop diagnosis on a field network in south east of France, Agron. Sustain. Dev. 25, 213-223.

Dejoux J.F. (1999). Evaluation d'itinéraires techniques du colza d'hiver en semis très précoces, Analyse agronomique, conséquences environnementales et agronomiques, Thèse INA-PG, 244 p.+ annexes.

Dejoux J.F., Ferré F., Meynard J.M. (1999) Effects of sowing date and nitrogen availability on competitivity of rapeseed against weeds in order to develop new strategies of weed control with reduction of herbicide use, 10th International Rapeseed Congress, Canberra, Australia, 1999/09/26-29, CD-Rom New Horizons for an Old Crop.

Dejoux J.F., Recous S., Meynard J.M., Trinsoutrot I., Leterme P. (2000) The fate of nitrogen from winter-frozen rapeseed leaves: mineralization, fluxes to the environment and uptake by rapeseed crop in spring, Plant Soil, 257-272.

Dejoux J.F., Meynard J.M., Reau R., Roche R., Saulas P. (2003) Evaluation of environment friendly crop management systems for winter rapeseed based on very early sowing dates, Agronomie 23, 725-736.

Delden A. van, Lotz L.A.P., Bastiaans L., Franke A.C., Smid H.G., Groeneveld R.M.W., Kropff M.J. (2002) The influence of nitrogen supply on the ability of wheat and potato to suppress Stellaria media growth and reproduction, Weed Res. (Oxford) 42, 429-445.

Doré T., Sebillotte M., Meynard J.M. (1997) A diagnostic method for assessing regional variations in crop yield, Agr. Syst. 54, 169-188.

Dorsainvil (2002) Évaluation par modélisation de l'impact environnemental des modes de conduite des cultures intermédiaires sur les bilans d'eau et d'azote dans les systèmes de culture, Thèse de doctorat, INA-PG Paris, p. 124.

Dosdall L.M., Herbut M.J., Cowle N.T., Micklich T.M. (1996) The effect of tillage regime on emergence of root maggots (Delia spp.) 
(Diptera: Anthomyiidae) from canola, Can. Entomol. 128, 11571165 .

Dosdall L.M., Florence L.Z., Conway P.M., Cowle N.T. (1998) Tillage regime, row spacing, and seeding rate influence infestations of root maggots (Delia spp.) (Diptera: Anthomyiidae) in canola, Can. J. Plant Sci. 78, 671-681.

Ekbom B., Ferdinand V. (2003) Field oviposition rates and egg load dynamics of pollen beetles (Meligethes aeneus Fab.) (Colepotera: Nitidulidae), Agr. Forest Entomol. 5, 247-252.

Feldman S.R., Alzugaray C., Torres P.S., Lewis P. (1997) The effect of different tillage systems on the composition of the seedbank, Weed Res. (Oxford) 37, 71-76.

Ferré F., Doré T., Dejoux J.F., Meynard J.M., Grandeau G. (2000) Évolution quantitative de la flore adventice dicotylédone au cours du cycle du colza pour différentes dates de semis et niveaux d'azote disponible au semis, in: Proceedings 2000 11th International Symposium on the Biology of Weeds, Dijon, France.

Gautronneau Y., Manichon H. (1987) Guide méthodologique du profil cultural, CEREF-GEARA, Lyon.

Jørnsgård B., Rasmussen K., Hill J., Christiansen J.L. (1996) Influence of nitrogen on competition between cereals and their natural weed populations, Weed Res. 36, 461-470.

Kirkegaard J.A., Sarwar (1998) Biofumigation of brassicae, Plant Soil 201, 71-89.

Lemaire G., Gastal F., Plenet D. (1997) Dynamics of N uptake and N distribution in plant canopies, Use of crop N status index in crop modelling, Diagnostic procedures for crop N management, Poitiers (France), November 22-23, pp. 15-29.

Lutman P.J.W., Dixon F.L. (1991) The competitive effects of volunteer barley (Hordeum vulgare), Ann. Bot. 117, 633-644.

Lutman P.J.W., Bowerman P., Palmer G.M., Whytock G.P. (1995) A comparison of the competitive effects of eleven weed species on the growth and yield of winter oilseed rape, in: Proceedings of the Brighton crop protection conference: weeds. Proceedings of an international conference, Brighton, UK, 20-23 November 1995, Vol. 3, pp. 877-882.

Lutman P.J.W., Risiott R., Ostermann H.P. (1996) Investigations into alternative methods to predict the competitive effects of weeds on crop yields, Weed Sci. 44, 290-297.

Lutman P.J.W., Bowerman P., Palmer G.M., Whytock G.P. (2000) Prediction of competition between oilseed rape and Stellaria media, Weed Res. 40, 255-269.

Maillet (1992) Contribution à la modélisation du nombre d'inflorescences produites par le colza d'hiver, Thèse de Doctorat INA P.-G., Paris, $186 \mathrm{p}$.
Merrien A., Pouzet A. (1988) Principaux facteurs limitant les rendements de colza d'hiver dans les conditions françaises physiologie et élaboration du rendement du colza d'hiver, Cetiom, Paris, pp. 16-19.

Meynard J.M., David G. (1992) Diagnostic de l'élaboration du rendement de blé, Cahiers Agricultures 1, 9-19.

Nilsson C. (1994). Pollen beetles (Meligethes spp.) in oil seed rape crops (Brassica napus L.), biological interactions and crop losses, $308 \mathrm{p}$.

Paolini R., Principi M., Froud-Williams R.J., Puglia S. del, Biancardi E. (1999) Competition between sugarbeet and Sinapis arvensis and Chenopodium album, as affected by timing of nitrogen fertilization, Weed Res. (Oxford) 39, 425-440.

Penfold C.M., Miyan M.S., Reeves T.G. (1995) Biological farming for sustainable agricultural production, Aust. J. Exp. Agr. 35, 849-856.

Primot S.,Valantin-morison M., Makowski D. (2005) Models for predicting high weed infestation in winter oilseed rape crops, Weed Res. $46,1-12$.

Renaud S. (1996) Prévention secondaire de l'infarctus par le régime, Rôle de l'acide alpha-linolénique, OCL 3, 169-172.

Smith B.J., Kirkegaard J.A. (2002) In vitro inhibition of soil microorganisms by (2-phenylethyl isothiocyanate, Plant Pathol. 51, 585-593.

Sylvester-Bradley R. (1985) Revision of a code for stages of development in oilseed rape (Brassica napus, L.), Asp Appl. Biol. 10, 395-400.

Trinsoutrot I., Nicolardot B., Justes E., Recous S. (2000) Decomposition in the field of residues of oilseed rape grown at two levels of nitrogen fertilisation. Effects on the dynamics of soil mineral nitrogen between successive crops, Nutr. Cycl. Agroecosys. 56, 125-137.

Valantin-Morison M., Meynard J.M., Doré T. (2007) Crop management and environment effects on insects in organic winter oil seed rape (WOSR) in France, Crop Prot. 26, 1108-1120.

Vos J., van der Putten P.E.L. (1997) Field observations on nitrogen catch crops. I potential and actual growth and nitrogen accumulation in relation to sowing date and crop species, Plant Soil 195, 299-309.

Welsh J.P., Bulson H.A.J., Stopes C.E., Froud-Williams R.J., Murdoch A.J. (1999) The critical weed-free period in organically-grown winter wheat, Ann. App. Biol. 134, 315-320.

Whytock C. (1993) The competitive effects of broad-leaved weeds in winter oilseed rape. Brighton crop protection conference, weeds, Proceedings of an international conference, Brighton, UK, 22-25 November.

Williams I.H., Darby R.J., Leach J.E., Rawlinson C.J. (1991) An analysis of factors affecting yield in winter rape, in Rapeseed in a Changing World, Proceedings of the Eighth International Rapeseed Congress, Ed. Mc Gregor DI GCIRC, Saskatoon, Canada, 9-11 July 1991, pp. 612-616. 